\title{
カメラアイ
}

\section{5 世紀に“光”をあてた古墳}

奈良国立文化財研究所木全 敬蔵

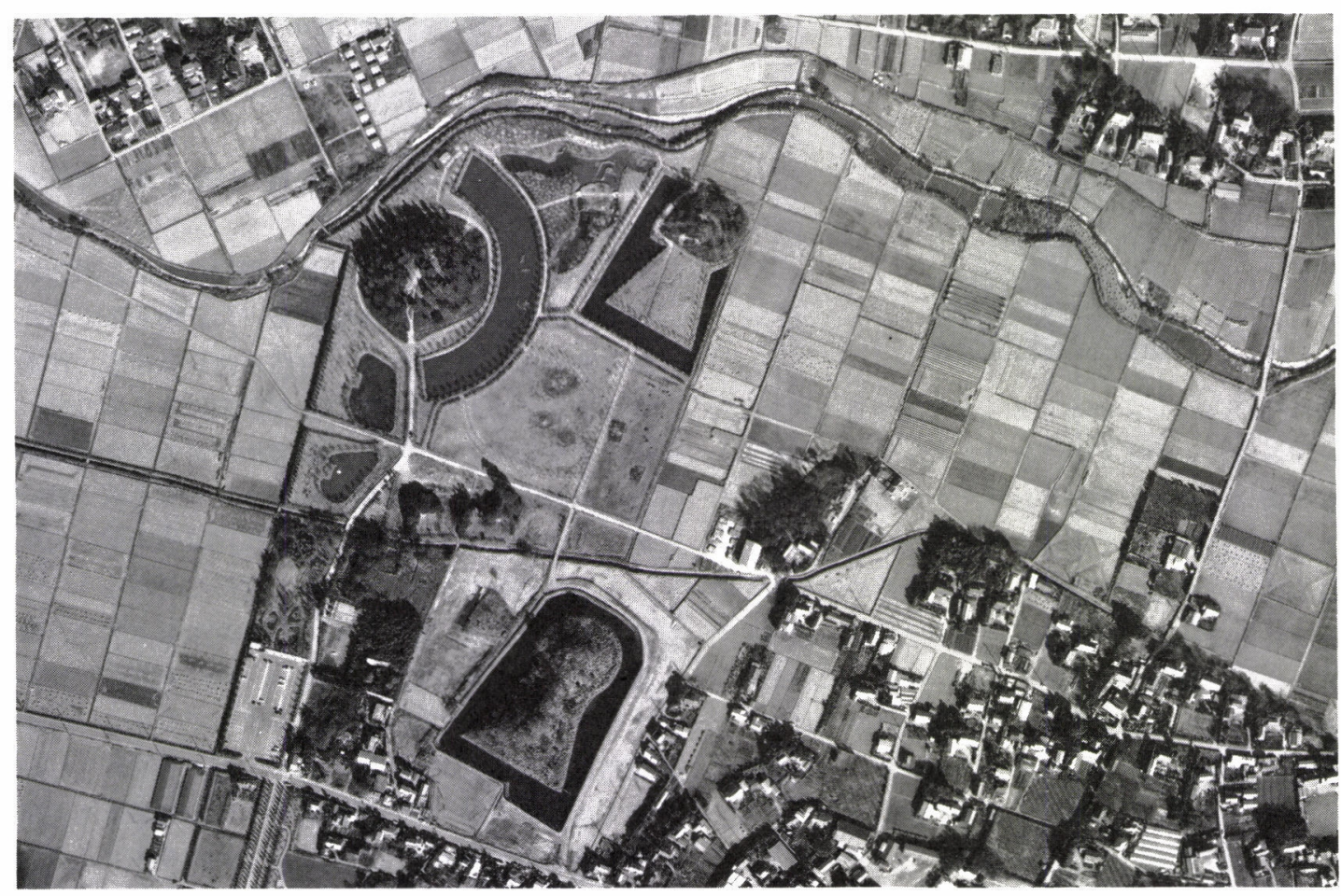

写真 1 昭和 53 年 12 月撮影

（さきたま資料館提供）

埼玉古墳群のうちの 1 基である稲荷山古墳（写真 1 の中央上寄りの前方後円墳）から出土した鉄剣の保存処理 をしていた元興寺文化財研究所の女性が「世紀の大発見」のきっかけを作った。さび取り作業中に金の微粒子に 気づき，金を使った細工がほどこされているのではないかとレントゲンで調べたら，驚いたことには，115個の 文字が浮び上ってきたのである。この文字は大刀製作の由来を金象嵌で書き記したもので, 文字資料のほとんど 残されていない 5 世紀に光を当てる「100年に 1 度の大発見」とも言うべき価值ある発見であった。この金象嵌 の文字のことが新聞に発表されると, 古代史研究者に大きな衝撃を与えた。といらのは, 明治の初めに熊本県江 田船山古墳から出土した大刀にほどこされていた銀象嵌銘の中に記された天皇名を「たじひのみずはわけ大王（反 正天皇)」と読んできたのが, この発見により,「ワカタケル大王（雄略天皇）」と読んだほうがよいのではない かと, 定説を覆す意見が出され, 古代の統一国家の成立時期についての論議がいっそう活発になった。

稲荷山古墳は「ワカタケル」で有名になる前から一部の人々の間で名の通った遺跡であった。それは，写真 2 に示したように, 日本では極めて稀な, 遺跡のソイルマークがはっきりと見える航空写真を残しているからであ る。ヨーロッパでは, 航空機の発達とともに「空からの考古学」が発達し, 遺跡の写真判読がI次・II次の大戦 の間も中断することなく進められてきた。

森本六爾は, 昭和 6 年にイギリスのクロフオードの業績を紹介するとともに, 我国においても考古学の分野に 空中写真を活用寸べきであることを主張した。森本の願いは，50年後になって漸やく叶えられつつある。

写真 3 は, 地元出身の陸軍航空隊員が郷土訪問飛行の際撮影した貴重な作品である。 


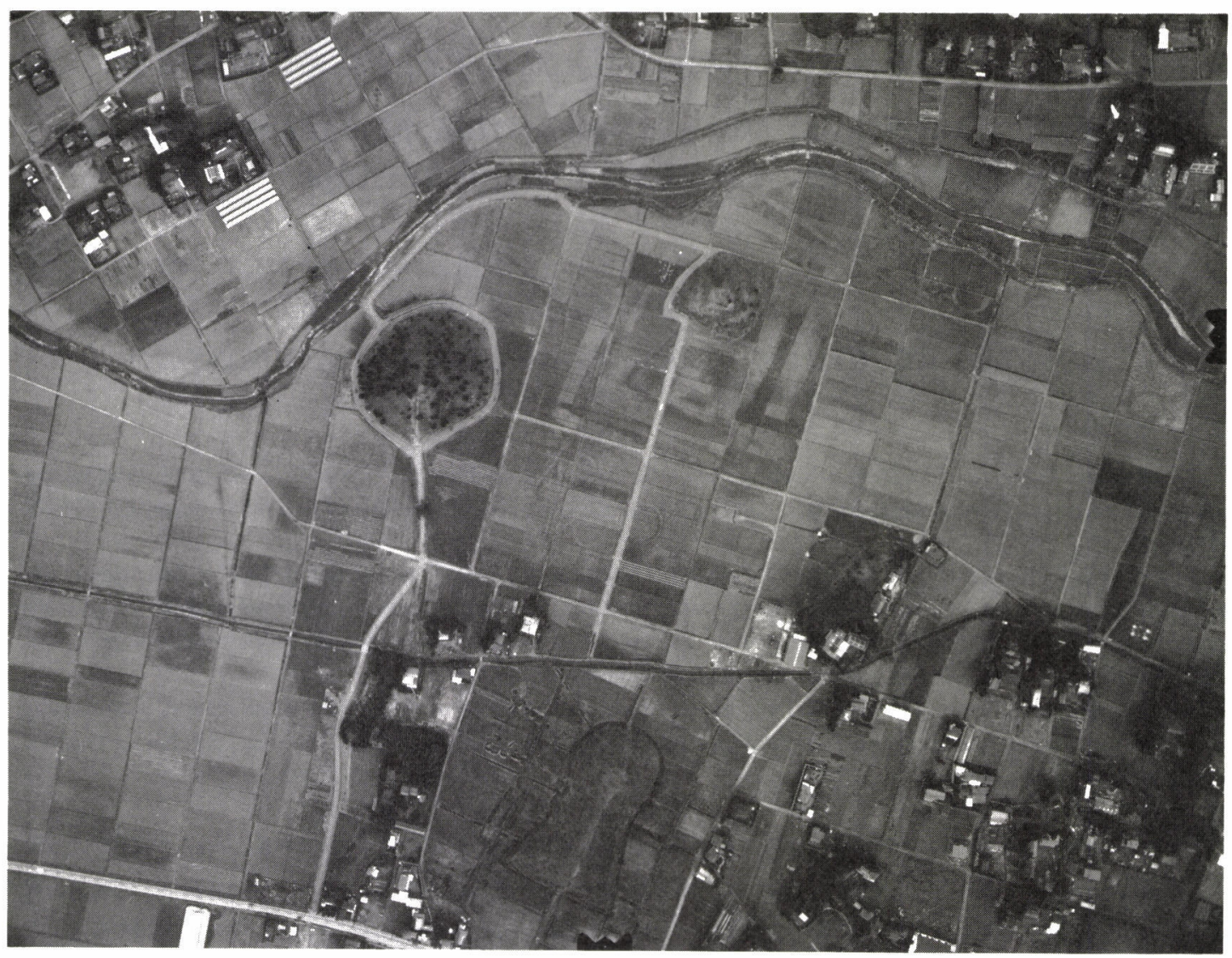

写真 2 昭和 44 年 1 月揘影

（さきたま資料館提供）

畄荷山古墳の削平された前方部が，又そのまわりには沢山の円墳の跡が、ソイルマークになって残っている。

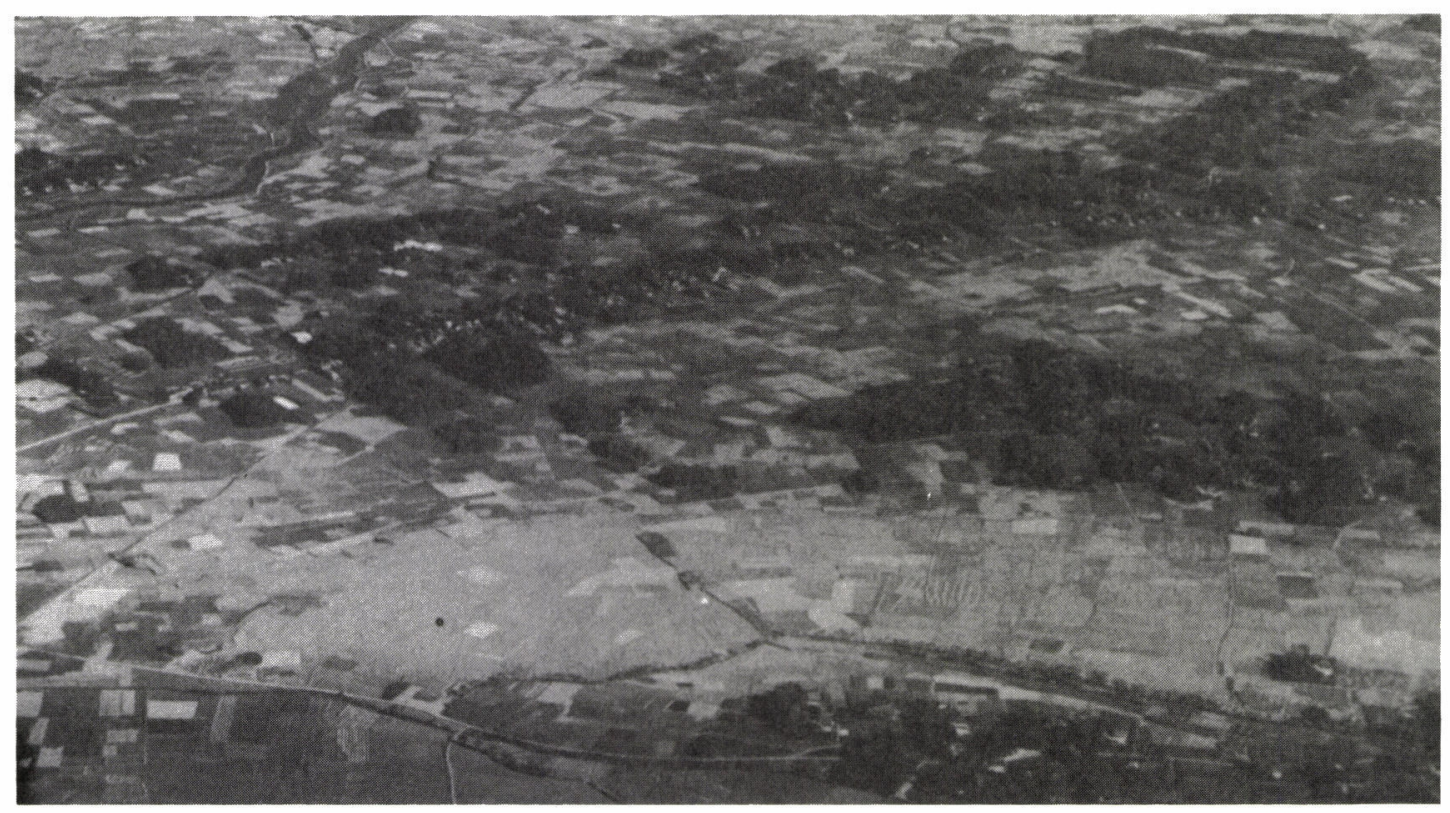

写真 3 昭和 5 年 11 月鼣影

(行田市提供)

昭和の初めには，耕地整理が進まず，古墳も無事であった。右下の水田の中に忍城水攻めの石田堤も見える。 